KAWISTARA

VOLUME 3

No. 2, 17 Agustus 2013

Halaman 117-226

\title{
KONSTRUKSI NASIONALISME DALAM NOVEL-NOVEL INDONESIA PRAKEMERDEKAAN (STUDENT HIJO DAN SALAH ASUHAN)
}

\author{
Wiyatmi \\ Jurusan Pendidikan Bahasa dan Sastra Indonesia \\ Fakultas Bahasa dan Seni, Universitas Negeri Yogyakarta \\ Email: wiyatmi_fbs@yahoo.co.id
}

\begin{abstract}
This paper aims to discuss construction of nationalism contained in Indonesian novels preindependence, especially Student Hijo and Salah Asuhan using perspective hegemony Gramsci's theory. The analysis showed that both the novel construct of ideology of nationalism against colonialism in the Dutch colonial era. Both novels also showed his duties as a battlefield of ideology of nationalism against colonialism.
\end{abstract}

Keywords: Nationalism, Studen Hijo, Salah Asuhan, Hegemony.

\begin{abstract}
ABSTRAK
Paper ini bertujuan membahas konstruksi nasionalisme yang terdapat dalam novel-novel Indonesia prakemerdekaan, khususnya Studet Hijo dan Salah Asuhan dengan menggunakan perspektif teori hegemoni Gramsci. Hasil analisis menunjukkan bahwa kedua novel tersebut mengkonstruksi ideologi nasionalisme melawan kolonialisme pada era penjajahan Belanda. Kedua novel juga menunjukkan tugasnya sebagai medan pertarungan ideologi nasionalisme melawan kolonialisme.
\end{abstract}

Kata Kunci: Nasionalisme, Student Hijo, Salah Asuhan, Hegemoni. 


\section{PENGANTAR}

Paper ini membahas konstruksi nasionalisme yang disampaikan dalam novel-novel Indonesia era prakemerdekaan, terutama novel Student Hijo dan Salah Asuhan dengan menggunakan perspektif teori hegemoni Gramsci. Pada perspektif hegemoni Gramsci novel dianggap sebagai salah satu jenis karya sastra yang dipercaya memiliki fungsi sosial seiring dengan zaman karya tersebut dilahirkan. Pada masa prakemerdekaan, sejumlah novel Indonesia telah ditulis oleh sejumlah sastrawan dalam upaya pembentukan nilai dan sikap nasionalisme. Paling tidak, ditemukan dua buah novel Indonesia yang terbit pada masa prakemerdekaan yang menyuarakan nasionalisme antara lain adalah Student Hijo (1918) karya Marco Kartodikromo dan Salah Asuhan (1927) karya Abdoel Moeis.

Artikel ini menggunakan perspektif teori hegemoni Gramsci untuk menguraikan bagaimana kedua novel tersebut telah ditulis oleh para pengarangnya untuk dijadikan arena pertarungan ideologi dalam konteks masyarakat kolonial. Pada novel Student Hijo dan Salah Asuhan digambarkan bagaimana nasionalisme dikonstruksi menjadi ideologi yang terus menerus melawan kolonialisme Belanda, sehingga cita-cita kemerdekaan Indonesia dapat terwujud.

Kata nasionalisme adalah serapan dari bahasa Inggris nationalism, berasal dari kata nation artinya bangsa. Bangsa menurut Benedict Anderson (1999: 7-8) didefinisikan sebagai 'komunitas' politis dan 'dibayangkan' sebagai sesuatu yang bersifat 'terbatas' secara inheren sekaligus 'berkedaulatan.' Dikatakan 'imajiner' (dibayangkan) karena para anggota bangsa terkecil sekalipun tidak akan tahu dan takkan kenal sebagian besar anggota lain, tidak akan bertatap muka dengan sebagian besar anggota lain itu, bahkan mungkin tidak pula mendengar tentang mereka. Meskipun demikian, di benak setiap orang yang menjadi anggota bangsa itu hidup sebuah bayangan tentang kebersamaan mereka. Dibayangkan sebagai 'terbatas' karena bangsa-bangsa memiliki garis-garis perbatasan yang pasti meskipun elastis. Di luar perbatasan itu adalah bangsa-bangsa lain. Dibayangkan sebagai 'berdaulat' karena bangsa memiliki otoritas untuk menaksir sendiri kebebasannya dalam hubungannya dengan bangsa lain. Dibayangkan sebagai 'komunitas' karena tak peduli akan ketidaksetaraan nyata dan eksplorasi yang mungkin lestari dalam tiap bangsa, sehingga bangsa itu sendiri dipahami sebagai kesetiakawanan yang mendalam dan mendatar.

Nasionalisme memiliki cakupan dan dimensi yang sangat luas, yang tidak hanya mengacu pada kesadaran suatu warga negara akan pentingnya ketunggalan bangsa, nation state, (Refly, 1993: 1), juga merupakan sebuah pandangan dunia (world view) yang mendasari dan sekaligus menjadi tujuan atau cita-cita bangsa. Pada praktik politik suatu negara, nasionalisme sering dioposisikan dengan kolonialisme, meskipun negara yang melakukan kolonisasi juga sebuah nation. Artinya ada bangsa yang mengkoloni dan ada yang dikoloni. Bagi bangsa yang mengkoloni, kehadiran mereka ke negaranegara yang dikoloni biasanya mengobral janji-janji tentang kemajuan, keberadaban, dan sejenisnya; meskipun subtansinya adalah melakukan penjajahan. Bagi mereka, negaranegara terjajah adalah kasar dan bar-bar, hanya memahami hidup sebagai kekerasan dan kekejaman semata; bangsa terjajah itu dianggap tidak seperti bangsa terjajah karena penjajahan sah dilakukan (Said, 1996: 11).

Di samping itu, nasionalisme merupakan konsep ideologis yang bersifat dinamis. Hal ini nasionalisme memiliki dinamika internal yang memungkinkan untuk berkembang sesuai dengan realitas sosial kemasyarakatan yang ada. Berdasarkan dinamikanya, nasionalisme pada dasarnya dapat dibedakan menjadi tiga tahap, yaitu (1) nasionalisme gelombang pertama atau nasionalisme prakemerdekaan; (2) nasionalisme gelombang kedua atau nasionalisme pascakemerdekaan; dan (3) nasionalisme gelombang ketiga atau nasionalisme Indonesia baru (Soedjatmoko, 1991; Alisyahbana, 1991). Nasionalisme 
gelombang pertama (prakemerdekaan) terwujud dalam upaya bangsa Indonesia untuk merebut kemerdekaan dari penjajahan. Ada dua hal pokok yang melahirkan nasionalisme bangsa Indonesia pada awal abad XX, yaitu (1) ketidakberhasilan perjuangan lokal menentang politik adu domba dan teknologi perang Belanda dan penjajah lainnya, betapa pun gagah beraninya para pahlawan; (2) keberhasilan nasionalisme dalam membentuk atau mempertahankan negara sendiri menentang penjajahan asing, seperti Jerman, Italia, Turki, Cina, dan Jepang. Nasionalisme gelombang kedua (pascakemerdekaan) adalah nasionalisme dalam rangka mempertahankan kemerdekaan dan kesatuan bangsa, serta mengisi kemerdekaan. Makna kemerdekaan di sini tidak semata-mata hanya aspek politis, tetapi juga merdeka secara ekonomis dan kultural. Nasionalisme gelombang ketiga (Indonesia Baru) adalah nasionalisme yang bersifat terbuka, yang tidak hanya merujuk pada batas wilayah kenegaraan dan kebangsaan (Soedjatmoko, 1991; Alisyahbana, 1991).

\section{PEMBAHASAN}

\section{Konstruksi Nasionalisme dalam Novel Indonesia Prakemerdekaan: Student Hijo dan Salah Asuhan}

Novel Student Hijo karya Marco Kartodikromo dan Salah Asuhan karya Abdoel Moeis merupakan dua buah novel Indonesia yang terbit pada masa prakemerdekaan yang cukup sarat mengangkat problem nasionalisme. Marco maupun Moeis selain sebagai penulis novel, ternyata aktif dalam gerakan nasional. Keduanya pernah menjadi pengurus dalam Serikat Islam. Moeis selalu menanamkan semangat perlawanan kepada anggota Serikat Islam. Ia juga mendirikan Komite Bumiputera bersama tokoh-tokoh pergerakan nasional lainnya sebagai perlawanan terhadap rencana Pemerintah Belanda yang akan merayakan hari kemerdekaannya yang ke seratus di Indonesia (Ensiklopedia Tokoh Indonesia).

Marco Kartodikromo merupakan salah seorang pengarang dan jurnalis pribumi pada masa kolonial Belanda. Pada buku sejarah sastra karya Ajip Rosidi (1969), pangarang ini dicacat sebagai pengarang di luar penerbit Balai Pustaka yang pada zamannya karya-karyanya, termasuk Student Hijo oleh pemerintah kolonial Belanda dianggap sebagai bacaan liar yang bertendensi politik. Catatan pemerintah kolonial Belanda, Marco telah dianggap sebagai musuh pemerintah kolonial. Data biografi Marco, tercatat bahwa dia memang merupakan orang yang dianggap berbahaya bagi pemerintah kolonial, sehingga berkali-kali dijebloskan ke penjara. Bahkan, pada tahun 1935 Marco meninggal dalam penjara di Bowen, Digul setelah bertahun-tahun dipenjara (sampul belakang Student Hijo, 2000). Beberapa karya Marco, termasuk Student Hijo dan Sama Rasa dan Sama Rata ditulis ketika dia dipenjara oleh Belanda. Pada masa kolonial Belanda, buku-buku Marco dilarang beredar.

Di samping dikenal sebagai sastrawan, sebenarnya Marco Kartodikromo merupakan salah seorang pelopor pers pribumi. Melalui pers, Sinar Hindia, Marco berjuang melawan imperialisme dan kolonialisme (Siregar, 1964: 25). Dia pun dianggap sebagai wartawanpenulis yang revolusioner (Siregar, 1964: 26). Dikarenakan sikap itulah, maka dia dianggap sebagai jurnalis radikal (Anderson, 1993: 41). Di samping seorang sastrawan dan jurnalis, pada masanya Marco juga menjadi tokoh Serikat (Dagang) Islam, sebelum akhirnya menjadi tokoh Partai Komunis Indonesia (Siregar, 1964: 23; Anderson, 1993: 41).

Student Hijo diterbitkan diterbitkan pertama kali sebagai cerita bersambung di harian Sinar Hindia (1918). Terbitan dalam bentuk novel pertama kali pada tahun 1919 oleh penerbit Masman dan Stroink di Semarang. Pemerintah kolonial Belanda menganggap novel ini sebagai salah satu "bacaan liar" yang peredarannya dilarang. Pada masa reformasi (2000) novel ini diterbitkan kembali oleh penerbit Aksara Indonesia dan Bentang. Salah Asuhan diterbitkan pertama kali oleh penerbit Balai Pustaka 1927. Berbeda dengan Student Hijo yang dianggap sebagai "bacaan liar," oleh pemerintah kolonial Belanda, Salah Asuhan 
merupakan salah satu novel yang dapat diterima oleh pemerintah kolonial Belanda. Artinya, isi novel tersebut dianggap tidak bertentangan dengan politik kolonial, seperti yang tertuang dalam Nota Rinkes yang menjadi visi dan misi penerbit Balai Pustaka. Beberapa puluh tahun kemudian, baru terungkap bahwa novel Salah Asuhan yang diterbitkan Balai Pustaka itu merupakan versi revisi dari naskah pertama yang dikirimkan Moeis ke Balai Pustaka. Salah Asuhan diterbitkan pertama kali tahun 1927 oleh penerbit Balai Pustaka. Sebelum terbit novel itu telah "tidur" di kamar Balai Pustaka selama lebih dari setahun (Hunter dalam Foulcher dan Day, ed., 2006: 162). Seperti dikemukakan Hunter (dalam Foulcher dan Day, ed., 2006: 162), dalam surat yang ditulis oleh Abdoel Moeis didapatkan informasi bahwa setelah lebih dari setahun pengarang mengirimkan novel Salah Asuhan ke penerbit Balai Pustaka, dia menulis surat kepada penerbit, yang isinya antara lain sebagai berikut.

Karya itu (Salah Asuhan) sudah berada di kantor anda selama lebih dari dua tahun, dan saya masih menunggu keputusan. Barangkali bagian-bagian yang menggelitik di sana sini harus dihilangkan, atau isi mereka diutarakan dengan cara lain. Saya siap penuh untuk melakukan perbaikan-perbaikan itu karena, ijinkan saya mengulangi, novel ini sama sekali tidak dimaksudkan untuk memperlebar kesenjangan antara Timur dan Barat...

Setelah mengirimkan surat tersebut, Moeis kemudian mengubah sebagian cerita dari novelnya. Perubahan tersebut, seperti dikemukakan Hunter (dalam Foulcher dan Day, ed., 2006:161) adalah pada bagian cerita yang berhubungan dengan penyebab perceraian Hanafi dan Corrie, serta penyebab kematian Corrie. Dalam Salah Asuhan yang diterbitkan Balai Pustaka, seperti yang dapat kita baca sekarang, perceraian tersebut terjadi karena Hanafi menuduh istrinya telah berbuat serong dengan laki-laki lain dengan perantaraan Tante Lien, tanpa ada buktinya. Setelah bercerai dengan Hanafi, Corrie ke Semarang dan bekerja di rumah yatim piatu, sampai dia meninggal dunia karena menderita sakit kolera. Cerita ini merupakan versi revisi dari cerita sebelumnya. Corrie digambarkan sebagai seorang perempuan yang suka bersolek dan menyukai pergaulan bebas. Corrie memiliki hubungan dengan seorang pemain keroncong bernama Jantje. Gaya hidupnya yang mewah sangat membebani suaminya. Kemewahannya mendorongnya menjadi pelacur umum dan ia mati ditembak oleh salah seorang anak buah hatinya karena iri hati (Hunter (dalam Foulcher dan Day, ed., 2006: 161).

Dalam situasi dan kondisi kolonial Belanda, maka cerita Salah Asuhan versi pertama, tampak terlalu merendahkan citra ras Eropa, sehingga tidak dapat diterima oleh penerbit Balai Pustaka. Pada versi kedua citra Corrie sebagai representasi ras Eropa di hadapan pribumi Hindia Belanda (Hanafi) tampak lebih terhormat. Perubahan pada detil cerita Salah Asuhan menunjukkan adanya kompromi yang dilakukan oleh Moeis dengan penerbit Balai Pustaka.

Penerbit Balai Pustaka sebagai penerbit novel Salah Asuhan berada dalam kuasa kolonial, maka konstruksi nasionalisme yang terdapat dalam Salah Asuhan disampaikan secara halus dan simbolis. Hal ini berbeda dengan nasionalisme dalam Student Hijo disampaikan secara eksplisit. Salah Asuhan konstruksi nasionalismenya tampak pada ideologi yang hendak disampaikan dalam novel tersebut, yaitu ideologi antiBarat atau antikolonial. Ideologi tersebut memandang Barat sebagai musuh yang akan menghacurkan identitas dan tatanan Timur. Judul Salah Asuhan yang mengacu pada tragedi perjalanan hidup Hanafi yang menunjukkan pada pembaca bahwa model pendidikan Belanda (Barat) yang dilakoni oleh Hanafi telah menjadikannya sosok yang ingkar terhadap tanah air dan keluarga yang melahirkannya. Hanafi telah menjadi korban dari eksperimen ibunya yang semula begitu percaya pendidikan model Belanda, seperti tampak pada data berikut. 
Dari kecil Hanafi sudah disekolahkan di Betawi, yaitu tidak dinantikan tamatnya bersekolah Belanda di Solok, melainkan dipindahkan ke ibu kota itu, karena kata ibunya ia tidak hendak kepalang menyekolahkan anak tunggal yang sudah kehilangan ayah itu. Sebab ibunya ada di dalam berkecukupan, dapatlah ia menumpangkan Hanafi di rumah orang Belanda yang patut-patut. Maksud orang tua itu ialah supaya anaknya menjadi orang pandai, melebihi kaum keluarganya dari kampong (Moeis, 1999: 23).

Kehancuran Hanafi setelah mendapatkan pengakuan kewarganegaraan yang setara dengan orang Eropa (kebijakan gelijkstelling) dan menikah dengan Corrie, yang berlanjut pada perceraian dan kematiannya akibat bunuh diri, merefleksikan pandangan dunia yang menganggap Barat sebagai sesuatu yang berbahaya dan harus dikritisi oleh pribumi. Pandangan tersebut juga tampak pada renungan Hanafi di puncak frustrasinya, sebelum dia bunuh diri.

Hanafi berbaring di tempat tidurnya, menutup mukanya dengan kedua telapak tangannya, menyadari untungnya yang malang. Makin bersalah ia, bahwa hidupnya di dunia ini tak mungkin akan mendapat aman dan damai, karena segala keberatan orang tidak dapat disertainya. Sementara itu berharaplah supaya anaknya, Syafei, jangan menurut jejaknya kelak. Biarlah anak itu menerima pelajaran Barat secukupnya sedang segala kebiasaan Timur yang burukburuk boleh dibuangnya dan digantinya dengan adat kebiasaan orang Barat yang baik, tapi sebab ia orang Timur, hendaklah asuhannya itu tetap menurut cara Timur juga... (Moeis, 1999: 236).

Pada perspektif hegemoni Gramsci tampak bahwa dalam novel Salah Asuhan terdapat pertarungan ideologi nasionalisme melawan kolonialisme dan budaya Barat. Kolonialisme dan budaya Barat telah melemahkan rasa nasionalisme Hanafi, sehingga menyia-nyiakan keluarga pribuminya untuk selanjutnya mengajukan persamaan kewarganegaraan yang setara dengan orang Eropa (kebijakan gelijkstelling) dan menikah dengan Corrie. Akan tetapi, kesadaran nasionalisme Hanafi, yang sudah lama terkubur dalam kesombongan dan ambisinya untuk setara dengan Eropa, pada akhirnya muncul juga. Perjalanan pulang ke Solok di atas sebuah kapal dia bertemu dengan orang Belanda yang sedang membaca dan mendiskusikan isi surat kabar Belanda yang terbit di Betawi.

Di dalam kapal Hanafi merasa kesedihan pula, yang rasa mengiris-iris hati jantungnya. Seorang penumpang sedang membaca sehelai surat kabar Belanda yang terbit di Betawi, yang sudah masyhur bencinya kepada Bumiputra. Surat kabar itu memperkatakan hal pertunangan seorang student bangsa Indonesia di Nederland dengan seorang nona, yang sama-sama menuntut ilmu di sekolah tinggi dengan dia. Bukan sedikit nista dan maki dituliskan oleh surat kabar itu terhadap kepada kaum Bumiputra yang terpelajar terhadap kepada ethische politiek dan lain-lain, sedang banyak nama-nama orang besar bangsa Belanda di Betawi turut dinodai. Sudah kejilah tulisan itu, bertambah keji pula buah tutur orangorang penumpang kapal yang duduk berhampiran dengan yang membaca surat itu... (Moeis, 1999: 234).

Konstruksi nasionalisme juga tampak dari suara sahabat Hanafi, Piet yang menyadarkan Hanafi mengenai perasaan kebangsaan dalam pergaulan pribumiBelanda, Timur-Barat, serta pandangan orang terhadap pilihan identitas kebangsaan seseorang. Piet, yang orang Belanda totok, membukakan mata Hanafi untuk melihat dan menyadari bahwa orang lebih menghargai derajatnya sebagai manusia, apabila dia tetap bertahan sebagai warga negara Indonesia, walaupun mendapat pendidikan Barat (Belanda)

Han, engkau sungguh terpelajar, tapi di dalam rasa dengan rasa itu engkau seolaholah buta dan tulis. Tidak dapat kuterangkan selanjut-lanjutnya tapi insaflah engkau, pada rasa bangsaku, engkau masih Bumiputra, dan engganlah mereka menerima engkau, 
bila engkau menyerbukan diri memasuki bangsa itu. Pada pendapat mereka, lebih tinggilah derajatmu sebagai manusia, bila engkau tinggal kekal di dalam bangsamu saja... (Moeis, 1999: 210).

Konstruksi nasionalisme yang digambarkan dalam Student Hijo tampak ekspilit dan radikal. Melalui tokoh-tokoh dalam Student Hijo, seperti R. Potronojo (orang tua Hijo), Hijo, Tumenggung Jarak, Wardoyo, dan beberapa orang yang terlibat dalam organisasi Serikat Islam ideologi nasionalisme direpresentasikan. Mereka digambarkan sebagai tokoh pribumi yang memiliki sikap, pikiran, dan pandangan yang menolak dan mencoba melawan hegemoni pemerintah kolonial Belanda. Mereka juga dihadapkan dengan tokoh-tokoh lain baik dari kalangan pribumi yang menjadi pegawai pemerintah kolonial Belanda maupun orangorang Belanda yang berposisi sebagai kaum kolonial, seperti Sersan Djepris, Walter, dan orang-orang yang ditemui Hijo di negeri Belanda.

Penggambaran perlawanan terhadap hegemoni kolonial Belanda, maka konstruksi nasionalisme tampak jelas pada novel Student Hijo.

"Saya ini seorang saudagar saja, kamu tahu sendiri, ini waktu orang seperti saya masih dipandang rendah oleh orang-orang yangjadi pegawainya gouvernement. Kadangkadang kita punya sanak sendiri yang sama turut gouvernement, dia tidak suka kumpul dengan kita, sebab pikirannya dia orang ada lebih tinggi derajadnya daripada kita orang yang sama jadi saudagar atau tani. Maksud saya buat mengirim Hijo ke negeri Belanda itu tidak lain supaya orang-orang yang merendahkan kita orang ini bisa mengerti bahwa manusia itu sama saja, tandanya anak kita bisa belajar juga seperti anaknya regent-regent atau pangeran-pangeran..." (Kartodikromo, 2000: 2-3).

Jiwa nasionalisme Hijo pun menyala ketika dia menginjakkan kakinya di negeri Belanda karena dia menemukan penduduk Belanda yang begitu menghormatinya karena dari penampilannya tampak Hijo mampu secara ekonomi.

Waktu itu Hijo turun dari kapal, di pelabuhan sudah berdesak-desakan orangorang yang datang dengan kapal Gunung. Keadaan itulah sungguh luar biasa bagi Hijo. Bukan karena kebagusan pakaian orangorang yanga da di situ, tetapi luar biasa sebab mulai ini waktu Hijo bisa memerintah orang-orang Belanda, orang mana kalau di tanah Hindia kebanyakan amat besar kepala...( Kartodikromo, 2000: 58).

Sesudahnya Hijo dan Leeraar-nya turun dari kapal, terus ke hotel, kedatangannya di situ Hijo dihormat betul oleh sekian budak hotel, sebab mereka memikirkannya, kalau ada orang yang baru datang dari tanah Hindia, mesti banyak uang, lebih-lebih kalau orang Jawa. Dari itu, Hijo tertawa dalam hati melihat keadaan serupa itu, karena dia ingat nasib bangsanya yang ada di tanahnya sana dihina oleh bangsa Belanda kebanyakan (Kartodikromo, 2000: 58).

Dari kutipan tersebut tampak bagaimana orang tua Hijo (R. Potronojo), sebagai pribumi sebenarnya ingin melawan dan menundukkan orang-orang Belanda dan antek-anteknya (orang-orang pribumi yang menjadi pegawai Belanda). Motivasi Potronojo menyekolahkan Hijo ke Belanda adalah untuk membukakan mata dan menyadarkan mereka bahwa orangorang pribumi tidak harus dipandang rendah. Kesadaran nasionalisme Hijo juga timbul setelah dia sampai di Belanda dan menyaksikan orang-orang Belanda, terutama dari kalangan bawah, dengan menunduknunduk melayani Hijo dan gurunya, yang menyadarkan Hijo bahwa tidak seharusnya bangsanya diperintah oleh Belanda. "Kalau negeri Belanda dan orangnya itu cuma begini ini keadaannya, betul tidak seharusnya kita orang Hindia mesti diperintah oleh orang Belanda" Begitu kata Hijo dalam hatinya (Kartodikromo, 2000: 59).

Berbeda dengan Hanafi dalam Salah Asuhan yang terbawa arus budaya Belanda setelah mendapatkan kesempatan 
pendidikan Belanda, Hijo dalam Student Hijo, menjadi sadar akan diri dan bangsanya yang berada dalam kekuasaan kolonial Belanda. Hanafi, karena terbawa arus dan hanyut, maka menjadi binasa, sementara itu karena sadar dan melawan, Hijo pun selamat dan membawa spirit nasionalismenya. Dikarenakan terbit pada masa kolonial Belanda, kehadiran kedua novel tersebut sangat penting artinya sebagai pembawa suara nasionalisme. Keduanya menunjukkan bahwa berperang melawan kolonialisme tidak hanya dapat dilakukan melalui senjata fisik, tetapi juga dapat dilakukan melalui wacana simbolis, melalui pena, melalui karya sastra. Marco Kartodikromo telah membuktikan hal itu, sehingga novel Student Hijo dilarang peredarannya dan dianggap sebagai "bacaan liar", sementara Abdoel Moeis harus berkompromi untuk untuk merevisi Salah Asuhan.

Konstruksi nasionalisme prakemerdekaan yang diusung dalam kedua novel tersebut secara kontekstual dapat dikatakan merefleksikan realitas yang terjadi di Indonesia atau Hindia Belanda pada masa kolonial Belanda. Di samping itu, dalam perspektif teori hegemoni Gramsci, konstruksi nasionalisme dalam kedua novel tersebut menunjukkan keberadaannya sebagai salah satu bagian dunia gagasan, atau ideologi yang dianggap memiliki kekuatan untuk memformasi masyarakat (Faruk, 1994: 61). Sebagai salah satu situs hegemoni, karya sastra merupakan ajang pertarungan bagi pembentukan blok historis secara hegemonik. Di sini karya sastra berfungsi sebagai pemelihara pemersatu blok sosial yang menyeluruh, sebagai penyemen dan alat pemersatu antara kekuatan-kekuatan sosial yang sesungguhnya bertentangan (Simon, 2001). Keadaan seperti ini novel menjadi ajang pertarungan tindakan kolektif bagi kelompok subordinat untuk melakukan perlawanan atau cunterhegemoni. Kerangka berpikir demikian ini, maka Salah Asuhan dan Student Hijo hadir sebagai novel yang mencoba melakukan cunterhegemoni terhadap kolonialisme Belanda.

\section{SIMPULAN}

Novel Student Hijo karya Marco Kartodikromo dan Salah Asuhan karya Abdoel Moeis merupakan contoh dua buah novel Indonesia prakemerdekaan yang digunakan oleh pengarangnya sebagai sarana untuk mengkonstruksi ideologi nasionalisme. Kedua novel tersebut telah mencoba mengusung ideologi nasionalisme dan antikolonialisme untuk bertarung melawan ideologi kolonialisme Belanda pada tahun 1918-1920-an. Sebagai novel yang ditulis oleh tokoh pergerakan nasional dan diterbitkan oleh penerbit pribumi (pertama kali sebagai cerita bersambung di Sinar Hindia), Student Hijo lebih leluasa menggambarkan spirit antikolonial Belanda. Sementara itu, sebagai novel yang diterbitkan oleh penerbit Balai Pustaka, sebuah penerbit resmi milik pemerintah kolonial Belanda, maka spirit nasionalisme yang ada di dalamnya disampaikan secara halus dan simbolis. Nasionalisme dalam Salah Asuhan dikonfrontasikan dengan kekuatan kolonial Belanda dalam bentuk nilai sosial budaya yang memiliki kuasa untuk menghanyutkan dan menghancurkan identitas keindonesiaan tokoh yang rapuh. Dengan menggambarkan tragedi Hanafi, Salah Asuhan mengajak kita untuk kembali kepada rasa nasionalisme dan kritis terhadap nilai-nilai sosial budaya Barat.

\section{DAFTAR PUSTAKA}

Alisyahbana, Sutan Takdir. 1991. "Kerja Lebih Keras dan Raih yang Terdepan," dalam Prisma, Nomor 2, Tahun XX Februari 1991.

Anderson, Benedict. 1993. Komunitaskomunitas Imajiner: Renungan tentang Asal-usul dan Penyebaran Nasionalisme. Edisi Bahasa Indonesia, diterjemahkan oleh Omi Intan Naomi. Yogyakarta: Pustaka Pelajar \& Insist Press.

Ensiklopedi Tokoh Indonesia: Abdoel Moeis. Diunduh dari Google. com. 05 Juli 2009. 
Faruk. 1994. Pengantar Sosiologi Sastra: dari Strukturalisme Genetik sampai Postmodernisme. Yogyakarta: Pustaka Pelajar.

Hunter, Thomas. 2006. "Identitas, kecemasan, ambiguitas dalam Salah Asoehan," dalam Keith Foulcher dan Tony Day. Clearing a Space: Kritik Pasca Kolonial tentang Sastra Indonesia Modern. Jakarta: Yayasan Obor dan KITLV.

Kartodikromo, Marco. 2000. Student Hijo. Yogyakarta: Yayasan Aksara Indonesia.

Moeis, Abdoel 1999. Salah Asuhan. Jakarta: Balai Pustaka. Cetakan ke-25.

Rosidi, Ajip. 1969. Ikhtisar Sejarah Sastra Indonesia. Bandung: Bina Cipta.

Refly, H.Z. 1993. "Nasionalisme, Universalisme, dan Struktur Kesadaran." Makalah dalam Panel
Forum Indonesia Pasca-Nasional, diselenggarakan di Universitas Gadjah Mada, Yogyakarta 21-22 April 1993.

Said, Edward W. 1996. Kebudayaan dan Kukuasaan: membongkar Mitos Hegemoni Barat. Bandung: Mizan.

Simon, Roger. 2001. Gagasan Politik Gramsci. Yogyakarta: Pustaka Pelajar dan Insist. Cet. Ke-3.

Siregar, Bakri. 1965. Sejarah Sastera Indonesia Modern. Jakarta: Akademi Sastera dan Bahasa Multatuli.

Soedjatmoko 1991. "Nasionalisme sebagai Prospek Belajar," dalam Prisma, Nomor 2 Tahun XX, Februari 1991.

Utomo, Cahyo Budi. 1995. Dinamika Pergerakan Kebangsaan Indonesia: dari Kebangkitan hingga Kemerdekaan. Semarang: IKIP Semarang Press. 